Article

\title{
Assessing the Integration of Climate Change and Development Strategies at Local Levels: Insights from Muheza District, Tanzania
}

\author{
Giovanni Pilato $^{1, *}$, Susannah M. Sallu ${ }^{1,2, *}$ (D) and Marta Gaworek-Michalczenia ${ }^{1}$ \\ 1 Sustainability Research Institute, School of Earth and Environment, University of Leeds, \\ Leeds LS2 9JT, UK; eemfgm@leeds.ac.uk \\ 2 ESRC Centre for Climate Change, Economics and Policy, School of Earth and Environment, \\ University of Leeds, Leeds LS2 9JT, UK \\ * Correspondence: giovannipilato25@gmail.com (G.P.); s.sallu@leeds.ac.uk (S.M.S.)
}

Received: 12 December 2017; Accepted: 8 January 2018; Published: 12 January 2018

\begin{abstract}
Integration of climate change measures in local development planning and delivery of Climate Compatible Development (CCD) at local levels is widely advocated to assist achievement of the Sustainable Development Goals. Such integration is not straightforward, and limited knowledge on multi-level governance of CCD exists. To progress this critical enquiry, we build on the concept of Climate Policy Integration (CPI) to assess how climate change measures are integrated in local development planning. We investigate the existing institutional arrangements across local levels (village to district) and sectors, and the barriers to and opportunities for CCD within local government authorities (LGAs). Particularly, we draw on qualitative analysis of local development policy and interviews conducted with LGAs in Muheza District of Tanzania. Findings show that several barriers, including under-resourcing, unreliable information on climate impacts, and the lack of guidelines for climate-development in key national policies are hindering the process towards CCD in local development planning. This study suggests that building capacity both within LGAs and at the national level are required to achieve CCD at sub-national levels. Currently, measures to address climate change are mostly implemented by development partners, so coordination between LGAs and these external stakeholders is essential to ensure consistency between climate and development objectives. Finally, our findings support a flexible approach to CCD, where emphasis on each of the three components of $\mathrm{CCD}$-mitigation, adaptation, and development-can vary across time and space.
\end{abstract}

Keywords: climate change; adaptation; mitigation; development; climate compatible development; local government authorities

\section{Introduction}

Climate change and development interact in a 'circular fashion' [1] (p. S3). On the one hand, climate change is a stressor to development efforts, as its impacts might hinder the accomplishment of development objectives, such as good health and food security. On the other, current and future development pathways, and their related greenhouse gas (GHGs) emissions, will determine the magnitude of climate change, as well as the capacity of future societies to mitigate and adapt to climate change.

The link between climate change and development and the realisation that future climate change is unavoidable have led to calls to reconsider development pathways. In particular, it has been argued that development pathways should incorporate climate change objectives, through the consideration of mitigation and adaptation measures. In 2010, the concept of Climate Compatible Development (CCD), 
defined as "development that minimises the harm caused by climate impacts, while maximising the many human development opportunities presented by a low emissions, more resilient, future" [2] (p. 1), was proposed as having potential to promote a new way forward. CCD promotes consideration of development, adaptation, and mitigation activities together, minimising trade-offs between them and delivery of triple-wins solutions-i.e., the accomplishment of development objectives while reducing the risks posed by climate change through both adaptation and mitigation actions. In this sense, CCD is presented as a "new generation of development processes" [2] (p. 1), overcoming the longstanding separation of development, mitigation, and adaptation in both practice and scientific research.

Critical exploration of the CCD concept and its application in practice, is at an initial stage [3]. While literature has started to assess triple-wins projects in different sectors, mainly related to natural resources management [4], it has been pointed out that delivering CCD would require going beyond single projects. It is argued that adaptation, mitigation, and development objectives should be simultaneously addressed in policies and plans to incentivise relevant actors to engage with CCD [5]. Indeed, empirical literature suggests that relevant stakeholders do not always spontaneously pursue triple-wins and that trade-offs between the three dimensions of CCD might exist, e.g., adaptation measures might result in carbon intensive processes, compromising mitigation objectives [6]. Since climate change is a cross-cutting issue, affecting multiple aspects of human development, integrating climate change and development objectives would entail a coordinated approach in decision-making, involving multiple government sectors and levels. Yet, empirical research on multi-level governance is still limited within CCD literature. Research on CCD implications for policy and governance has mostly focused on the national level, with a lack of engagement with sub-national levels [5]. Sub-national levels are deemed to provide the opportunity for a flexible and place-based integration of climate change and development, based on contextual social and ecological factors. Moreover, local government authorities (LGAs) often have the mandate to implement both climate change and development strategies defined at higher administrative levels. Despite local levels' potential to deliver on CCD, LGAs notably face several barriers to the integration of climate change measures in local development planning and practice, such as under-resourcing or lack of proper information. However, a systematic analysis of the barriers to and the opportunities for CCD at local levels is lacking. The concept of CCD adds to the plethora of development theories. However, critics have stressed the need for a theoretical and empirical effort to "make sense of CCD as a concept" [3] (p. 2). As such, we focus here on the CCD concept with the aim to provide some clarification on the concept's relevance and potential application in practice at local levels.

In this paper, we develop and apply a framework to explore policy and governance aspects of CCD at local levels, with a focus on opportunities for and barriers to its operationalisation. The study focuses on Muheza District, Tanzania. Tanzania provides the opportunity for an insightful analysis on CCD operationalisation: the magnitude of projected climate change, the country's economic dependence on climate sensitive sectors (e.g., agriculture), urbanisation, population growth, and local communities' limited capacity to cope with climate variability make Tanzania vulnerable to climate change [7-9]. At the national level, Tanzania has developed the National Adaptation Plan of Action (2007), the Climate Change Strategy (2012), the National Strategy for REDD+ (2013), and the National Action Plan for REDD+ (2013), all published by the Vice President's Office [5]. However, it has been observed that national policies do not include 'efforts to manage short- and long-term climate risks' [10] (p. 2). Moreover, limited institutional capacity, along with financial, technical, and human resources, are hindering the implementation of these policies [11]. Together with NGO partners, Muheza District Council is engaged in a project that aims to build capacity to, and integrate climate change adaptation into district development planning. Thus, despite the absence of effective national institutional arrangements, the joint effort of the District Council and NGO partners might create a conducive context for the emergence of CCD in Muheza District. A systematic analysis of barriers to and opportunities for CCD in the district therefore provides an opportunity to identify suitable entry points to harness integration. Using a broad CCD framing, which encompasses both mitigation and 
adaptation, helps also to clarify the co-benefits offered by mitigation options, currently not explicit, nor integrated in the project.

The following section reviews the concept of CCD, explores its policy and governance implications, and presents the theoretical framework developed to analyse CCD mainstreaming in local development planning and governance, and barriers to and opportunities for CCD in LGAs. The methodology section presents the research approach and outlines further socio-economic details in Muheza District. Results are then presented, followed by a discussion that considers the findings in relation to literature on CCD and the Climate Policy Integration concept. Finally conclusions are drawn.

\section{Climate Compatible Development, Exploring the Concept and Its Application}

Mitchell and Maxwell [2] introduced CCD as a new development landscape, based on the integration of adaptation, mitigation, and development strategies in order to achieve 'triple-wins'. The concept of CCD proposes to explore the linkages that might exist between climate and development objectives [12]. Nunan [13] suggests that CCD processes should be transformative in nature, as its operationalization would involve disentangling development from fossil-fuel dependence, while at the same time eradicating poverty, addressing inequalities, and enhancing resilience to climate stressors. It is important to observe that CCD is not the only integrated approach to adaptation, mitigation, and development: concepts such as 'low carbon climate resilient development' or 'low emission climate resilient development', similarly to CCD, call for simultaneous responses to climate change and development [14]. According to Fisher [15], the distinctive character of CCD, compared to other integrated approaches, is its development-first approach, which would suggest the prioritisation of development over climate change objectives.

Some critics argue that CCD emphasis on triple-wins might overlook the possible tensions between adaptation, mitigation, and development objectives [4,16]. Empirical evidence shows that, in some cases, trade-offs between the three dimensions of CCD might exist. For instance, adaptation strategies might result in high carbon emissions or put a burden on development objectives [17]. At the same time, long-term climate action might not be a political priority, as other short-term development challenges exist (e.g., food security, water supply, healthcare, and education) [18]. Moreover, adaptation and mitigation are usually implemented within different sectors: mitigation planning usually involve the energy and the transport sectors, and is linked to national planning and policymaking; on the other hand, adaptation involves actors in a wider range of sectors (agriculture, natural resources management, tourism, water, and coastal management) [16]. Klein et al. [12] observe that, in some cases, mitigation and adaptation benefits might be higher if they are treated and implemented separately. For these reasons, Tanner et al. [19] pointed out that CCD should be considered a dynamic, rather than a static, process: different emphasis might be put on each of its components, and the contribution from adaptation, mitigation, and development, as well as their degree of integration, might change over time and space. As a result, Tanner et al. [19] suggest that CCD processes can take different modalities over time and space, according to the contribution of each component and to the political priorities.

Stringer et al. [5] point out that so far CCD is not established in development practice. For instance, CCD is not practiced in international and national political arenas $[5,13]$. As a result, the assessment of options linking adaptation and mitigation with development is at the initial stage [4]. In particular, opportunities for CCD identified so far are mainly in ecosystem management and in the agriculture sector through the concept of climate smart agriculture. Suckall et al. [12] observe that opportunities for triple-wins exist and are being implemented in other sectors (e.g., energy, water). However, they are rarely reported as CCD; instead, they are framed as either adaptation or mitigation projects. For instance, reforestation programs mainly have a mitigation frame, whilst their potential adaptation benefits are generally overlooked [6]. 


\subsection{Policy and Governance Implicaions of $C C D$}

The operationalization of CCD requires changes in institutional arrangements in order to facilitate the integration of climate change and development strategies. Some authors point out that development policy and planning is a cornerstone of CCD. Integrating climate change adaptation and mitigation in sectoral development policy and planning is argued to provide opportunities to deliver triple wins in the long term and to make an efficient use of scarce resources in developing contexts $[6,20,21]$. Suckall et al. [6] observe that climate mainstreaming in development policy is essential to reduce trade-offs between the three dimensions of CCD. Indeed, sound policy frameworks can constitute a solid and stable support for CCD activities, providing long-term incentives for relevant stakeholders to engage with climate change adaptation and mitigation [22]. However, evidence to date suggests that, at the national level, the acknowledgement of adaptation, mitigation, and development linkages appears to be limited in developing countries $[5,23]$.

Governance of CCD would require coordination across actors operating at multiple levels. Mitigation has traditionally involved actors at international and national levels [14]. On the other hand, adaptation is often framed as a local responsibility due to the spatial variation of climate impacts and vulnerabilities [24]. Whilst this framing has been criticised in the adaptation literature [25], it has been pointed out that adaptation, compared to mitigation, involves a wider set of actions ranging from the individual to the national level [16]. Moreover, evidence to date suggests that CCD governance would involve multiple stakeholders. For instance, Leventon et al. [21] noticed that the private sector could facilitate CCD implementation: in Zambia, extractive industries are implementing projects that are achieving triple wins, although without a CCD framing. Similarly, NGOs and community-level stakeholders are important in ensuring that climate objectives are consistent with development priorities at the local level [26,27]. Evidence from Southern Africa suggests that public-private partnerships and networks as well as inter-ministerial working-groups can enhance CCD $[17,21,26]$. As such, CCD governance would involve 'multiple government and non-government actors ... at several administrative levels' [13] (p. 249).

Some authors suggest that local levels need particular consideration in the integration of climate and development practice $[28,29]$. Although climate change affects the development at all scales, climate change impacts have a relevant degree of spatial variation $[18,30]$. For instance whilst climate change is projected to negatively impact agriculture in the East African region, in some areas within the same region (e.g., high altitude areas) crop yield might benefit from temperature increase [30]. Moreover, local levels provide important opportunities for a context-specific development and climate change integration through local development plans and joint action between local governments, the private sector, and citizens [24]. Wilbanks [29] (p. 282) points out that 'local scales offer potential for participation, flexibility and innovativeness'. However, local levels can have limited capacity, in terms of skills and resources, to address climate change [13,29]. Yet, research on CCD has focused on integration at national level [5], or on single small-scale projects delivering CCD rather than local level planning $[6,21]$. The presence and the effectiveness of institutional arrangements supporting climate change integration with development objectives at local levels has not been investigated.

Several barriers to the integration of climate change in development planning and policy have been identified. Ellis et al. [31] conducted a cross-country study on the challenges related to CCD policy processes. The analysis shows that barriers are related to political, resources, and information factors (Table 1). Short-termism from government officials that are driven by the preference for short-term economic growth over long-term climate benefits, powerful interest groups opposed to change (e.g., key industries), and the lack of a clear institutional mandate for climate change are the main political barriers to CCD [31]. Lack of adequate resources is another major barrier to CCD implementation. Indeed, the implementation of CCD options might impose additional costs to countries with relevant budgetary constraints [31]. Non-material resources, such as expertise or skills to engage with climate change, are also determinant in CCD implementation (Table 1). The lack of both material and non-material resources may also constrain state capacity to implement or enforce 
CCD strategies in place. Finally, decision-makers might lack access to evidence-based information on climate-related risks and response options.

Table 1. Drivers of, and barriers to, Climate Compatible Development (CCD).

\begin{tabular}{lll}
\hline \multirow{3}{*}{ Political } & \multicolumn{1}{c}{ Drivers } & \multicolumn{1}{c}{ Barriers } \\
\hline & $\begin{array}{l}\text { A recognised need at the national level to } \\
\text { adapt to climate change in order to bolster } \\
\text { resilience, achieve growth, and } \\
\text { reduce poverty }\end{array}$ & Short-termism \\
\cline { 2 - 3 } & Strong government leadership & Interest groups opposed to change \\
\cline { 2 - 3 } Resources & Desire to access climate finance and aid & Costs associated with change \\
\cline { 2 - 3 } & $\begin{array}{l}\text { Need for energy security and natural } \\
\text { resource efficiency }\end{array}$ & $\begin{array}{l}\text { A lack of state capacity to respond to and } \\
\text { implement strategies. }\end{array}$ \\
\cline { 2 - 3 } & $\begin{array}{l}\text { Desire to capitalise on new economic } \\
\text { opportunities }\end{array}$ & $\begin{array}{l}\text { Technological constraints and } \\
\text { uncertainties. }\end{array}$ \\
\hline \multirow{2}{*}{ Information } & & $\begin{array}{l}\text { A lack of awareness or trusted } \\
\text { information about uncertainties, risks, } \\
\text { opportunities, and trade-offs }\end{array}$ \\
\hline
\end{tabular}

Sources: Adapted from Ellis et al. [31].

The study from Ellis et al. [31] also highlighted some drivers for CCD. Strong government leadership and acknowledgment of the need to take climate action at the national level are identified as important political drivers. The desire to access international climate finance schemes, such as REDD+ or the Green Climate Fund, is another driver for CCD, especially in developing countries [31]. Investments in renewable energy sources to achieve national energy security and the need to preserve ecosystem services for natural resources efficiency can stimulate progress towards CCD in some key sectors, such as energy and agriculture. Finally, innovative technologies integrating climate and development objectives, such as renewable sources of energy, can provide new economic opportunities that incentivise CCD processes. However, a systematic analysis of barriers to and opportunity for CCD, allowing for generalisation or comparative studies, has not been undertaken in the academic research.

\subsection{Towards a Framework for Analysing Barriers to and Opportunities for CCD Mainstreaming at Local Levels}

For the purpose of this study, a framework to analyse the integration of climate change in development planning at local levels, as well as the presence of institutional arrangements supporting this integration, was developed. The framework is based on the concept of Climate Policy Integration (CPI). Di Gregorio et al. [23] (p. 36) define CPI as "the integration of multiple policy objectives, governance arrangements and policy process related to climate change mitigation, adaptation and other policy domains". This definition is useful to link CPI research agenda with policy and governance aspects of CCD.

In order to analyse the presence of policy and governance arrangements for the integration of adaptation, mitigation, and development strategies in Muheza District, the framework is based on the concepts of internal and external policy coherence, and of vertical and horizontal policy integration, as defined by Di Gregorio et al. [23] and presented in Table 2. Internal policy coherence (between mitigation and adaptation objectives) refers to the support of co-benefits and the minimisation of trade-offs between climate change mitigation and adaptation in policy documents and strategies; external policy coherence (between climate and non-climate objectives) refers to the support of co-benefits and the minimisation of trade-offs between climate and non-climate objectives in policy documents and strategies. The concept of policy integration refers to governance arrangements for the integration of climate and development strategies. In particular, vertical policy integration refers to the presence 
of institutional arrangements to include climate change objectives within a sector at different levels; horizontal policy integration refers to governance structures and processes that allow for the coordination on climate and development integration across different sectors [23]. Since policy integration and policy coherence take the three domains of adaptation, mitigation, and development into account, they are useful concepts for assessing CCD mainstreaming in development planning. These concepts were applied to this analysis of the integration between climate and non-climate development objectives at the local level and for the analysis of governance processes in place for this integration.

Table 2. Four dimensions of Climate Policy Integration (CPI).

\begin{tabular}{cll}
\hline & \multicolumn{2}{c}{ Administrative and Organisational Structures and Processes } \\
\cline { 2 - 3 } & \multicolumn{1}{c}{ Vertical CPI } & \multicolumn{1}{c}{ Horizontal CPI } \\
\hline \multirow{2}{*}{$\begin{array}{c}\text { Internal Climate } \\
\text { Policy Coherence }\end{array}$} & $\begin{array}{l}\text { Integrating climate change mitigation } \\
\text { WITH adaptation processes/objectives } \\
\text { across administrative responsibilities } \\
\text { within one sectoral domain }\end{array}$ & $\begin{array}{l}\text { Integrating climate change mitigation } \\
\text { WITH adaptation } \\
\text { processes/objectives across multiple } \\
\text { sectoral domains }\end{array}$ \\
\hline \multirow{2}{*}{$\begin{array}{c}\text { External Climate } \\
\text { Policy Coherence }\end{array}$} & $\begin{array}{l}\text { Mainstreaming mitigation OR adaptation } \\
\text { across administrative responsibilities }\end{array}$ & $\begin{array}{l}\text { Mainstreaming mitigation OR } \\
\text { adaptation across multiple } \\
\text { sithin one sectoral domain }\end{array}$ \\
\hline
\end{tabular}

Sources: Adapted from Di Gregorio et al. [23].

The framework also aims to assess factors facilitating or hindering CCD mainstreaming in development planning at sub-national levels. To this aim, some features from Moser and Ekstrom's [32] framework to analyse barriers to planned adaptation were integrated into the framework. Moser and Ekstrom [32] conceptualise the adaptation process as a linear process encompassing three sequential phases, presented in Table 3: the understanding phase, which involves problem detection, information gathering, and problem definition; the planning phase, which involves the development, assessment, and selection of options; and the managing phase, which involves the implementation of options, and their monitoring and evaluation. Although the decision-making process described in Moser and Ekstrom's [32] framework is acknowledged to be too simplistic, it was integrated into the analytical framework for this study as it allowed us to capture in which stage of the decision-making process barriers are more relevant. Indeed, barriers can manifest at each stage and prevent progress in the process. Moser and Ekstrom [32] observe that common barriers to planned adaptation can be categorised by leadership, resources, information and communication, and values and belief.

Table 3. Schematised climate integration process.

\begin{tabular}{cll}
\hline Phase & & \multicolumn{1}{c}{ Sub-Stages } \\
\hline \multirow{3}{*}{ Understanding } & - & Problem detection \\
& - & Information gathering \\
& - & Problem definition \\
\hline \multirow{3}{*}{ Planning } & - & Development of options \\
& - & Assessment of options \\
& - & Selection of options \\
\hline \multirow{2}{*}{ Managing } & - & Implementation of options \\
& - & Monitoring \\
& - & Evaluation \\
\hline
\end{tabular}

Source: adapted from Moser and Ekstrom [32].

Whilst the framework from Moser and Ekstrom [32] was developed to target planned adaptation, in this research it was used to assess barriers to and opportunities for both adaptation and mitigation integration in development planning. As observed by Tompkins and Adger [33], the factors determining 
adaptive capacity and mitigative capacity are similar. Moreover, except for the category values and belief, there is an overlap between barriers identified by Moser and Ekstrom [32] and the preliminary analysis from Ellis et al. [31]. The only additional element in Moser and Ekstrom's [32] framework is the category 'values and belief'. Moser and Ekstrom [32] point out that values and beliefs influence risk perception and acceptability of adaptation measures for social groups. Thus, the category is considered in this study, to assess whether it is relevant in CCD processes.

The framework is presented in Table 4. Whilst the list of factors derived from Moser and Ekstrom [32] is useful to initiate a systematic analysis of barriers to, and opportunities for CCD, it is not comprehensive. Thus, empirical research will help understanding, first, what barriers are more relevant at different scales, and, second, if there are other relevant factors supporting or hindering CCD.

Table 4. Framework to analyse climate policy integration aspects of CCD as well as the barriers to, and opportunities for, CCD.

\begin{tabular}{|c|c|c|}
\hline \multicolumn{3}{|c|}{ Policy Coherence } \\
\hline $\begin{array}{l}\text { Internal } \\
\text { External }\end{array}$ & \multicolumn{2}{|c|}{$\begin{array}{l}\text { Integration between adaptation and mitigation } \\
\text { Integration between climate and development objectives }\end{array}$} \\
\hline \multicolumn{3}{|c|}{ Policy Integration } \\
\hline \multirow[t]{2}{*}{$\begin{array}{c}\text { Vertical } \\
\text { Horizontal }\end{array}$} & $\begin{array}{l}\text { - Governance structures that facilita } \\
\text { sectoral policies } \\
\text { - } \quad \text { Governance structures for cross-se }\end{array}$ & $\begin{array}{l}\text { mainstreaming of CC into } \\
\text { oral coordination }\end{array}$ \\
\hline & Barriers & Opportunities \\
\hline Leadership & $\begin{array}{l}\text { Political leaders unwilling to } \\
\text { engage with CCD }\end{array}$ & $\begin{array}{l}\text { - Political leaders willing to engage } \\
\text { with CCD }\end{array}$ \\
\hline Resources & \begin{tabular}{ll}
\multicolumn{2}{l}{ Lack of: } \\
- & Financial resources \\
- & Expertise \\
- & Technology \\
\end{tabular} & $\begin{array}{ll}\text { Availability of: } \\
-\quad \text { Financial resources } \\
-\quad \text { Expertise } \\
-\quad \text { Technology } \\
\end{array}$ \\
\hline $\begin{array}{l}\text { Information and } \\
\text { Communication }\end{array}$ & $\begin{array}{l}\text { Absence of: } \\
\text { - } \quad \text { Information on climate risks } \\
\text { - } \quad \text { Information on available options } \\
\text { to advance CCD } \\
\text { - } \quad \text { Communication mechanisms } \\
\text { across sectors and levels }\end{array}$ & $\begin{array}{l}\text { Presence of: } \\
\text { - } \quad \text { Information on climate risks } \\
\text { - } \quad \text { Information on available options } \\
\text { to advance CCD } \\
\text { - } \quad \text { Communication mechanisms } \\
\text { across sectors and levels }\end{array}$ \\
\hline Values and beliefs & $\begin{array}{ll}\text { - } & \text { Low perceived risk } \\
\text { - } & \text { Unacceptability of CCD measures }\end{array}$ & $\begin{array}{ll}\text { - } & \text { High perceived risk } \\
\text { - } & \text { Acceptability of CCD measures }\end{array}$ \\
\hline
\end{tabular}

Sources: adapted from Di Gregorio et al. [23] and Moser and Ekstrom [32].

\section{Research Methodology}

This research followed a single-case study approach allowing examination of CCD without overlooking the specificity of the institutional and political context: as pointed out in previous research on CCD, contextual factors play a determinant role in shaping CCD outcomes [4]. Muheza District is one of eight districts in the Tanga region, Northeast Tanzania (Figure 1). 


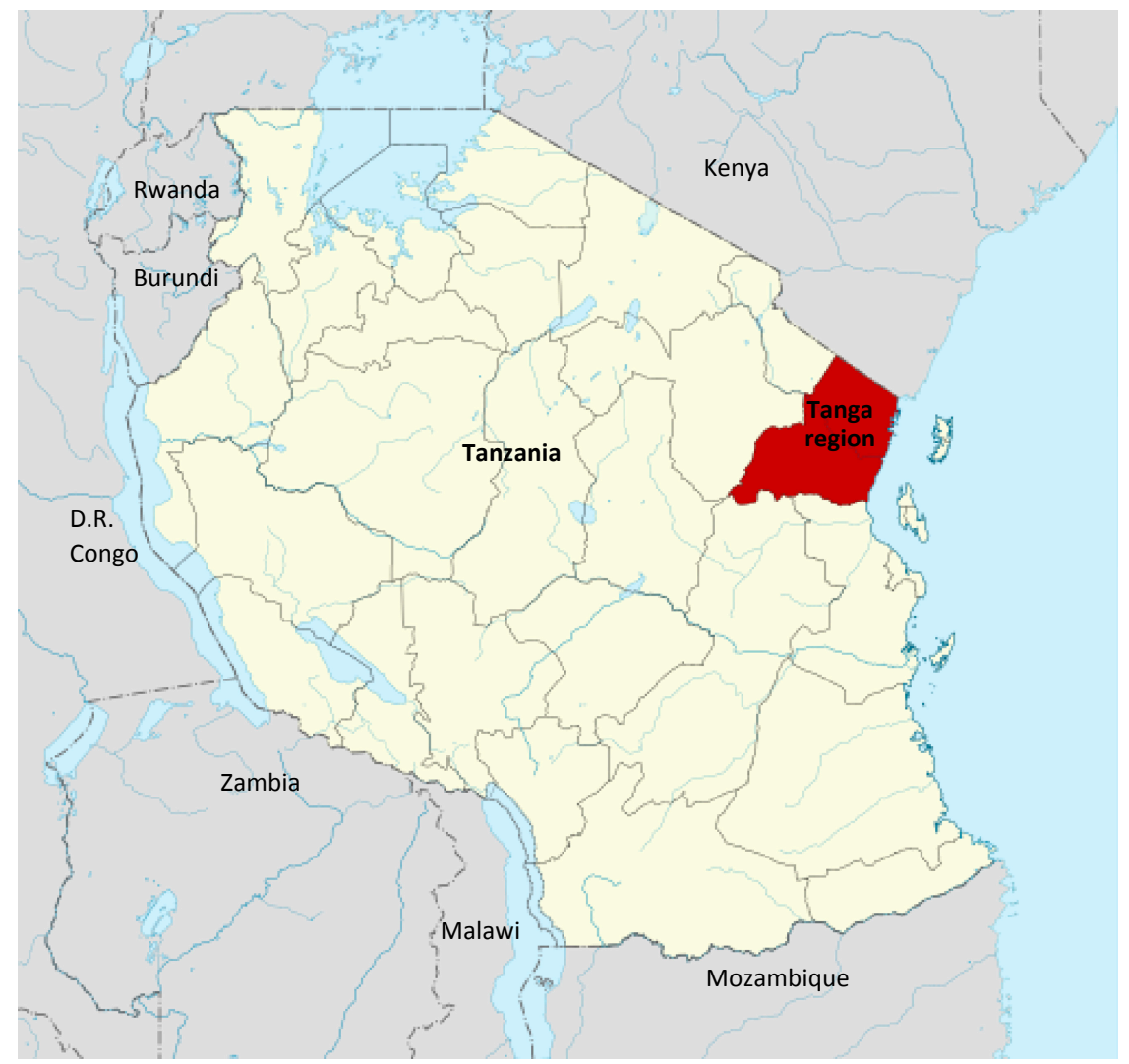

Figure 1. Tanga region location, adapted from Sémhur [34].

Both socio-economic and climatic contexts make Muheza District a relevant case study for research focusing on CCD processes. Muheza District is mainly a rural area; it is sub-divided in 4 divisions, 23 wards, and 175 villages, where most of the population ( $88 \%$ of the total) live [35]. The district economy and local livelihoods are heavily reliant on climate sensitive sectors. Agriculture employs $83 \%$ of the population and is dependent on rainfall. Both food crops, including maize, banana, and cassava, and cash crops, including tea, rubber, and spices (cinnamon, cardamom, and cloves) are produced [35]. Forestry is another important economic sector in the district: nine forest reserves and two nature reserves (Amani and Nilo) have been established in Muheza District for the protection of water catchments and the provision of forest products to local communities. Muheza District is currently facing several development issues; many of them relate to the provision of services. For instance, only $6 \%$ of the households have access to electricity, and firewood and charcoal are the main source of energy for cooking [35]. Whilst Muheza District has more health facilities compared to other districts in the Tanga region, health services are still lacking, as dispensaries (where first aid and routine medical treatment are given) are not present in every village. Only $55 \%$ of the population within the district is supplied with water and almost $18 \%$ of the households are lacking sanitation systems [35].

Muheza District is characterised by a varied topography, which includes four agro-ecological zones: coastal plains, dry plains, wet plains, and mountainous zones [35]. As a result, climatic conditions display a certain degree of spatial variability in the district, with average temperatures ranging from $24{ }^{\circ} \mathrm{C}$ in the highlands to $32{ }^{\circ} \mathrm{C}$ in the lowlands [7]. As the rest of the region, Muheza District experiences bimodal rainfall patterns; however, within the district average, annual rainfall displays spatial variability. Climate projections at the national level suggest that climate change will have relevant spatial variability within the district: rain seasons are projected to be more intense but shorter for areas with bimodal rainfall pattern and drier for areas with unimodal rainfall pattern, while temperatures are expected to increase [8]. 
Concerns about climate change have led Muheza District Council to accept and collaborate with a European Commission-funded NGO-led project that is implementing integrated approaches for climate change adaptation in eight villages of the East Usambara Mountains, whilst also trying to integrate climate change adaptation into district development planning. A systematic analysis of barriers to and opportunities for CCD can help identify suitable entry points to harness integration, whilst using a broad CCD framing can also help clarify the co-benefit offered by mitigation options currently not integrated in the project.

\subsection{Data Collection}

A qualitative approach was applied to explore meanings associated with development and climate change processes, and to investigate the perceived barriers to and opportunities for integrating climate change in development planning. Evidence was collected from multiple sources using different methods. The research involved both primary and secondary data.

Secondary data was obtained from the analysis of the Muheza District 5 Year Development Plan (5YDP). Since the current Development Plan was not yet available, the 5YDP (2011-2012 to 2016-2017) [36] was analysed. Document analysis was fundamental to explore development planning in Muheza District and to investigate external and internal policy coherence. Secondary data obtained from document analysis were triangulated with primary data in order to compare official development planning with local level actors' interpretation of development.

Primary data were collected in December 2016. Semi-structured interviews with 28 key-actors from different sectors and sub-national levels were conducted. Interviewees included district and ward officers, and village leaders allowing for the collection of different views on development and climate change across local actors. At the district level, the District Executive Director, Heads of the Agriculture, Forestry, Land and Environment Departments, and the District Planning Officer were interviewed. At the ward level, semi-structured interviews were conducted with Executive Officers from two remote highland wards, Misalai and Zirai. Zirai Ward Education Officer and Zirai Ward Councillor were also interviewed. At the village level, village leaders in eight villages (Misalai, Mgambo, Kazita, Kwemsoso, Shambangeda, Zirai, and Kwelumbisi) were interviewed. Village leaders included Village Chairmen (8), Village Executive Officers (7), and Chairmen of Village Natural Resource or Village Environmental Committees (3). Interviews focused on the following themes with a focus on Muheza District: (a) perception of climate change and variability; (b) perception of impacts from climate change; (c) climate-development strategies in place; (d) development ambitions; (e) stakeholders' cooperation during extreme events; (e) information and communication on climate change (see Appendix A for the full list of questions).

Additional primary data were collected in July 2017 through two semi-structured interviews with staff from a national and an international NGO, both engaged in the integration of climate change measures in local development in Muheza District. Questions about NGO engagement with climate-change-related activities in Muheza District, as well as about perception on opportunities for and barriers to the integration of climate change and development, were asked (see Appendix A for the full list of questions).

\subsection{Data Analysis}

Data analysis followed a hybrid process of deductive and inductive thematic analysis [37], and took place in multiple stages. In the first stage, data analysis followed a directed content analysis approach: the conceptual framework introduced above was used to develop preliminary codes for analysis of CPI in Muheza District. First, policy coherence and integration were analysed. To assess policy coherence, the 5YDP was analysed and the passages discussing co-benefits and trade-offs between mitigation, adaptation, and non-climate objectives identified and coded. Interviews with district, ward, and village leaders were then used for triangulation and to assess policy integration. 
Next, the same interview material was analysed to investigate institutional arrangements conducive for vertical and horizontal climate integration at the local level.

In the second stage of analysis, barriers and opportunities for CCD were investigated. Interviews with district, ward, and village leaders, and with NGO staff were analysed through a hybrid process of deductive and inductive thematic analysis [37]. Directed coding, based on the Moser and Ekstrom [32] framework, was used for a primary investigation of barriers and opportunities for CCD: resources, information and communication, leadership, values and beliefs were used as codes. Since directed coding approaches might result in a biased analysis and risks overlooking contextual factors [38], the analysis of perceived barriers and opportunities was expanded through an inductive approach: codes emerging from the data, namely, institutional context and the role of external actors, were also included in the analysis. This was particularly useful to identify perceived opportunities for CCD. Overall, this process was useful to corroborate and expand the initial theoretical framework, as it was developed through academic contributions not directly related to CCD enquiry.

\section{Results}

\subsection{Climate Policy Integration in Muheza District}

\subsubsection{External and Internal Coherence}

The analysis of the 5YDP shows that external policy coherence between climate change and development is absent. In the development plan, the interpretation of development is aligned with the 2025 Tanzania Development Vision, the national development policy framework: the core objective is 'to have a community that enjoys high quality and sustainable living standards by 2025'. Four targets are further defined in the 5YDP: attaining a high quality livelihood; attaining good governance and the rule of law; building a strong and competitive economy; attaining a reliable water supply to all people. An improvement in infrastructure and a transition towards a more industrialised local economy, based on processing industries, are highlighted as the main actions to realise the district development objectives. However, climate change is not mentioned as a threat to local development, and mitigation or adaptation measures are not included. For instance, the impacts of climate change on water availability are not mentioned in the plan. From the interviews, it is unclear whether climate change has been integrated in the new 5YDP, as respondents provided contrasting answers on this point.

Though climate change is not included in the 5YDP, respondents at all levels (village, ward and district) mentioned a number of measures that are being implemented or planned to address extreme climate events and support local development. As such, it is unclear to what extent these activities address long-term climate change. The most reported activities, presented in Table 5, are in the agriculture and forestry sectors, and are planned or implemented to cope with extreme weather events, namely, droughts. In the agriculture sector, planting drought-resistant crops and diversifying livelihood activities are the most commonly reported measures implemented to cope with climate extremes and achieve development objectives, e.g., improve food security and increase income. One respondent from the District Council also mentioned the presence of plans for conservation agriculture, but it is unclear to what extent these are implemented, due to scarce funding. In the forest sector, forest conservation and co-management (in partnership with local nature reserves) were reported at all levels as measures in place to preserve the local natural environment and the local weather conditions, namely, rainfall patterns. Respondents at all levels also mentioned the development benefits of forest conservation and co-management, linked to the economic compensation local communities receive from Joint Forest Management. As for the water sector, some respondents from the District Council mentioned the implementation of small-scale irrigation systems to cope with droughts in the Misoswe Ward, an area not included in this research. The construction of the irrigation scheme is also mentioned in the 5YDP; moreover, the 5YDP reports that a feasibility study to assess the possibility of building an irrigation system in Zirai Ward has been conducted; however, this was not mentioned in interviews. The 5YDP, 
in contrast to respondents from the District Council, does not discuss the adaptation benefits linked to small-scale irrigation. Finally, one respondent from the District Council stated that villagers are being advised to adopt sustainable land management practices, namely, intercropping, terracing, and using mulch. Interestingly, none of the village leaders mentioned these measures, so it is unclear whether sustainable land management practices are being implemented or planned at the village level.

Table 5. Measures implemented or planned at the district and at the village level to integrate climate change in local development (derived from interviews with district officials and village leaders).

\begin{tabular}{|c|c|c|c|c|}
\hline \multirow{2}{*}{ Sector } & \multirow{2}{*}{ Measure } & \multicolumn{3}{|c|}{ Perceived gains } \\
\hline & & Adaptation & Mitigation & Development \\
\hline \multirow{3}{*}{ Agriculture } & Planting drought-resistant crops & $\begin{array}{l}\text { Reduced vulnerability } \\
\text { to droughts }\end{array}$ & - & Food security \\
\hline & Conservation agriculture & Preserve soil moisture & - & $\begin{array}{l}\text { Improved agricultural } \\
\text { production }\end{array}$ \\
\hline & $\begin{array}{l}\text { Diversifying livelihoods } \\
\text { (livestock keeping, beekeeping, } \\
\text { butterfly farming, agroforestry) }\end{array}$ & $\begin{array}{l}\text { Reduced vulnerability to } \\
\text { droughts }\end{array}$ & - & Income generation \\
\hline \multirow[t]{2}{*}{ Forest } & Forest conservation & Protect water catchment & $\begin{array}{l}\text { Preserve rainfall } \\
\text { Carbon } \\
\text { sequestration }\end{array}$ & REDD+ payments \\
\hline & Co-management & Protect water catchment & - & $\begin{array}{l}\text { Support to village } \\
\text { development from } \\
\text { partnership with forest } \\
\text { reserves }\end{array}$ \\
\hline Water & $\begin{array}{l}\text { Small-scale irrigation, } \\
\text { construction of small scale } \\
\text { irrigation }^{1}\end{array}$ & $\begin{array}{l}\text { Reduced vulnerability } \\
\text { to droughts }\end{array}$ & - & $\begin{array}{l}\text { Improved agricultural } \\
\text { production, } \\
\text { Food security }\end{array}$ \\
\hline Land & $\begin{array}{l}\text { Sustainable Land Management: } \\
\text {-intercropping } \\
\text {-terracing } \\
\text {-use of mulch }\end{array}$ & Preserve soil moisture & - & Food security \\
\hline
\end{tabular}

Note: ${ }^{1}$ In Misoswe District.

Respondents at all levels generally mentioned the adaptation and development benefits of these activities. For instance, shifting to drought-resistant crops and diversifying livelihood activities are implemented to enhance food security and increase household income, whilst coping with droughts (Table 5). However, awareness on the potential development benefits of some activities is sometimes partial. For example, only one respondent at the district level mentioned the potential development benefits from forest conservation, related to REDD+ payments. On the other hand, respondents are generally unfamiliar with the concept of mitigation. At the village level, forest conservation and reforestation are perceived as 'mitigation' measures to restore or preserve traditional rainfall patterns within the district. However, carbon sequestration is rarely mentioned as a measure to address climate change: only one respondent from the District Council mentioned the mitigation benefits offered from carbon sequestration through forest conservation. Interviewees at all levels do not report co-benefits from adaptation to mitigation-and vice versa. For instance, agroforestry is usually framed as an adaptation measure - to reduce soil degradation and provide alternative livelihoods - but the co-benefit to mitigation, through enhanced carbon sequestration, is not mentioned by the interviewees at any level. Thus, internal coherence is not acknowledged.

\subsubsection{Vertical and Horizontal Integration}

In Muheza District, the presence of an overarching institutional mandate for horizontal and vertical integration is unclear. As for horizontal integration, interviews at the district level suggest that across departments it is not always clear where the mandate for climate change lies. Several respondents identify the District Executive Director (DED) as the central authority with the mandate on climate 
change issues. However, one respondent from the District Council stated that this mandate is currently being delegated to the Environment Department, due to the lack of expertise on climate change within the DED. As a result, some respondents tend to identify the Environment Department as responsible for the climate issue in the district. Yet, coordination across sectors is limited: one respondent from the District Council stated that departments tend to work in isolation. As for vertical integration, the agriculture sector, compared to the other sectors, has a governance structure that favours the implementation of climate strategies at lower levels: respondents at all levels reported that extension officers are present at the ward and village levels to advise farmers on agriculture strategies to cope with climate extremes. Some respondents from the District Council mentioned the presence of environmental units in some Ministries that should foster the inclusion of climate measures within each sector's activities. However, their influence at the district level is unclear, as there are no formal sectoral plans for climate change at the district level.

\subsection{Perceived Barriers to Climate Compatible Development}

Interviews at all administrative levels and with development partners suggest the presence of multiple barriers affecting the integration of climate change and development objectives, presented in Table 6. Barriers affect the understanding, the planning, and the managing phases of the integration process of climate and development.

Table 6. Identified barriers to climate integration (derived from interviews with district officials, village leaders, and NGO staff).

\begin{tabular}{|c|c|c|}
\hline Phase & Barrier & Implication \\
\hline \multirow{3}{*}{ Understanding } & Lack of technology & Insufficient collection of weather information \\
\hline & Ineffective communication & Misconception of climate impacts \\
\hline & Lack of weather information & Uncertainty in climate impacts \\
\hline \multirow{4}{*}{ Planning } & Lack of financial resources & Impossibility to develop plans \\
\hline & Lack of expertise on CC & $\begin{array}{l}\text { Impossibility to include climate change in } \\
\text { local planning }\end{array}$ \\
\hline & Limited information on options & Limited assessment of options \\
\hline & $\begin{array}{l}\text { Lack of national sectoral } \\
\text { guidelines (water, energy sector) }\end{array}$ & Limited assessment of options \\
\hline \multirow{3}{*}{ Managing } & Lack of financial resources & Impossibility to implement planned actions \\
\hline & Lack of expertise and technology & $\begin{array}{l}\text { Impossibility to monitor eventual } \\
\text { mitigation options }\end{array}$ \\
\hline & Lack of political leadership & $\begin{array}{l}\text { Implementation of CC action dependent on } \\
\text { external actors' activities }\end{array}$ \\
\hline
\end{tabular}

\subsubsection{Under-Resourcing}

Lack of resources is a commonly reported barrier at all levels and it appears to be relevant in different stages of the integration process. Whilst different kinds of resources are mentioned in the interviews, financial resources are the most frequently reported. According to respondents from the District Council, insufficient funds from the national government are hindering the implementation of activities simultaneously addressing climate change issues and local development. For instance, one respondent from the District Council stated that scarce village revenues are hindering the preparation of the Village Land Use Management Plan (VLUMP) in line with national guidelines. According to the same respondent, VLUMPs would contain measures to promote a sustainable use of natural resources and could enhance measures to cope with climate extremes. Interviews at the village level suggest that insufficient funds from the national government also hamper the accomplishment of 
village development priorities. Some village leaders state that access to community development funds and microfinance schemes provide important financial opportunities for the villages. Respondents mainly referred to Village Community Bank (VICOBA), a micro-finance scheme managed and funded by local communities, and to the Tanzania Social Action Fund (TASAF), implemented by the central Government and funded by the World Bank to grant subsidies to the poorest households. Several villages were able to initiate income-generating activities (e.g., tree planting and beekeeping) financed through these programs.

Lack of resources also refers to the lack of technical resources and staff expertise. One respondent from the District Council pointed out that the implementation and monitoring of mitigation measures would be impossible in Muheza District, due to the lack of technology and expertise on carbon measurement. In general, interviews from the District Council suggest that expertise on climate change is limited within Muheza District, as it is a new issue. For instance, at the village and district levels, knowledge on the causes of climate change is generally limited to local factors, such as deforestation. According to one respondent from the District Council, the lack of expertise on climate change is the reason for the exclusion of climate change from the development plan. Thus, lack of resources appears to be a major barrier to the understanding, planning, and managing stages of climate change and development integration.

\subsubsection{Insufficient Information on Weather Variability and Options to Address Climate Change}

At all levels weather information on climate variability is deemed useful for agricultural planning. However, a lack of reliable weather information is generally perceived as a barrier to the integration of climate change in local development planning and practice, particularly in the understanding stage. The district receives a weather report from the Tanzania Meteorological Agency (TMA), which is then passed to the villages. One respondent from the District Council stated that the TMA report is not relevant to local planning, as it is released every three or four months. Respondents from the district and village level stated that the main sources of information on climate variability are TV and radio weather forecasts. However, it is unclear to what extent this information is available to local communities: some village leaders stated that not everyone in the village has access to radio or TV. Moreover, according to several village leaders, weather forecasts are unreliable as they cover the whole Tanga region and do not give proper information on local variations. According to the one respondent from the District Council and to some village leaders, the accuracy of weather information might be improved by installing more weather stations in the district, but this is currently unfeasible due to the lack of financial resources. Respondents at the district and village level explained that local communities rely on local knowledge and experience to predict weather and make decisions on agriculture activities.

As already pointed out (see Table 5), interviews at all levels suggest that information on options to integrate climate change and development mainly relates to adaptation measures in the agriculture and natural resources sectors. Measures in crucial sectors for local development, industry in particular (as stated in the 5YP), were not mentioned. Except for one respondent from the District Council with formal REDD+ training, mitigation options were not mentioned at any administrative level.

\subsubsection{Ineffective Communication across Levels}

Interviews at the village level suggest that under-resourcing affects communication between the District Council and local communities. A respondent from the District Council pointed out that, in the case of weather extremes, the district communicates information on agriculture strategies to wards and villages through agricultural extension officers. However, some village leaders pointed out that extension officers are not present in every village: they stated that one extension officer is usually responsible for several villages, but due to a limited time and means of transport meetings are very rare. An NGO respondent stated that this issue is particularly relevant for Zirai and Misalai Wards, as they are among the most remote areas in Muheza District. In some cases, miscommunication on 
challenges faced by villages seems related to misconception about villages' vulnerabilities. For instance, respondents at the district level tend to perceive villages in the highlands as less vulnerable to climate extremes, while leaders from highland villages reported that, in the case of droughts, local livelihoods can be severely affected.

\subsubsection{Competing Development Priorities}

It is not clear to what extent climate change is considered a priority for development practice across different levels. For instance, within the District Council, the interpretation of development varies across departments: whilst one respondent identified industrial growth and extractive industries as a key aspect of local development (in line with the 5YDP), others identified protection of natural resources, sustainable land management, and water supply as the development priorities. At the ward and village levels, the identified development objectives are not always closely related to climate change, as the most reported development priorities are infrastructures for health and education (e.g., building classrooms and/or dispensaries). Thus, although respondents at all levels acknowledge the need to address climate change, it is unclear to what extent climate change is a political priority compared to other development objectives.

\subsubsection{Lack of Political Leadership and Dependence on External Actors}

As pointed out above, there is no clear mandate for climate change in the district. Interviews at all levels suggest that the initiative to address climate change mostly depends on external actors (mainly national and international NGOs). NGO respondents stated that part of their organisations' work in the area involves providing the District Council with the technical support and information on policy options to integrate adaptation measures in local development planning. According to the same respondents, NGOs in the area are also engaged in raising awareness on climate change within the District Council. Respondents at all levels mentioned several activities conducted within NGO projects that help deal with climate change. Some of these have a development focus: they provide adaptation benefits by enhancing alternative livelihood activities. Many respondents pointed out that conservation projects include activities beneficial for climate objectives. For instance, the Pangani River Basin Management Project (a project implemented from the International Union for Conservation of Nature (IUCN), Netherlands Development Organization (SNV) and a local NGO to improve water management schemes and support the implementation of climate change adaptation measures within local communities [39]) is supporting the implementation of conservation agriculture, forest conservation and management, and irrigation. Similarly, the Eastern Arc Endowment Fund, a trust fund to finance community development and conservation projects in the Eastern Arc (including the East Usambara) Mountains, supported the provision of efficient wood stoves in some of the villages to reduce the use of fuel wood and deforestation. Finally, several village leaders pointed out that participatory forest management schemes provide another opportunity for the integration of climate change in local development. In particular, leaders from villages bordering Amani and Nilo nature reserves stated that local communities implemented alternative livelihood projects in cooperation with the nature reserves. It is important to observe that many of these projects do not have an explicit climate change focus, but respondents at the district and village level acknowledged their benefit for climate objectives.

Interviews at all levels show that external projects are deemed useful in many respects. Village leaders declared that through development and conservation projects villagers learnt about climate change issues. Respondents from the District Council pointed out that projects are important in the provision of skills and expertise on climate change measures that are lacking at the village level. For instance, through the Pangani River Basin Management Project, villages are receiving technical support to formulate their VLUMP. A respondent from the District Council pointed out that projects provide an opportunity for cooperation across different sectors. However, interviews with village leaders suggest that reliance on external partners can reduce local communities' attention for climate change 
issues. For instance, a village leader pointed out that, since partner NGOs are already including climate change measures in their projects, climate change is not a priority for village development. Moreover, reliance on external actors appears to tie the integration of development and climate change in the district to their agendas. For example, the presence of different NGOs and projects focused on conservation results in a predominance of climate change action in natural resources management, while measures in some key climate sectors, such as energy or health, are not being reported from local actors.

\subsection{Perceived Opportunities for Climate Compatible Development}

\subsubsection{Awareness on the Link between Environmental Degradation and Climate Change}

Belief in climate change is widespread across levels and sectors. At all levels, climate change is framed as an environmental issue: environmental degradation and deforestation at the local level are perceived as the cause of climate change. At the same time, respondents from the district and the village level consider the decrease in average rainfall within the district as the main risk associated with climate change. Only one respondent from the District Council mentioned the risks of climate change for human health.

One NGO respondent stated that the pre-existent understanding of the impact of local environmental degradation on climate change offer an opportunity for integrated approaches to development at the village level. According to this NGO respondent, environmental education might facilitate the implementation of reforestation and forest conservation activities, with simultaneous benefit for local development and climate change objectives.

\subsubsection{Institutional Framework}

The broader institutional framework, set up in national policies, appears to be another important factor influencing the integration of climate change and development objectives in Muheza District. According to an NGO respondent currently involved in integrating climate measures in Muheza District development planning, climate mainstreaming at the national level is a necessary condition for the inclusion of mitigation and adaptation at local levels. The same respondent stated that national policies represent guiding documents for development practitioners at sub-national levels. For instance, it was mentioned that Ministry of Agriculture is producing national guidelines on climate smart agriculture for development practice at the local level. At the same time, another NGO respondent stated that the integration of climate change in some key sectoral policies, such as water and energy, is still limited and do not provide specific details on measures to integrate climate and development at sub-national levels.

\section{Discussion}

The analysis of the four dimensions of CPI was useful to gain insight on both governance and policy aspects of CCD in Muheza District. In particular, the analysis of vertical and horizontal policy integration, based on Di Gregorio et al.'s CPI framework [23], was useful to investigate the presence of institutional arrangements for the integration of climate change in local development planning. Although horizontal and vertical integration are generally considered complementary strategies rather than alternatives, previous research in developing countries suggests that vertical approaches are predominant $[20,38]$. In Tanzania, the National Climate Change Strategy (NCCS) establishes the institutional framework for climate change issues, assigning responsibility for climate measures to the Division on Environment at the national level and to the Environment Department at the district level. However, this research highlighted that, in Muheza District, a horizontal approach to climate integration predominates, with a central authority (the District Executive Director (DED)) supposedly coordinating climate action across sectors. Horizontal approaches, if supported by technical expertise, might be more effective in delivering integration compared to vertical approaches [40]. For instance, 
it has been observed that horizontal arrangements can be more effective in building cross-sectoral coordination, useful to minimise inconsistency in climate and development strategies across different sectors $[38,40]$. However, it is important to observe that the lack of capacity to address climate change within the DED in Muheza District Council is hindering the effectiveness of this arrangement and that the Environment Department is currently being delegated the mandate to address climate change. This risks to undermine the integration of climate change and development, as environmental departments are unlikely to have a strong political influence on other sectors [23]. However, it is important to note that, since a consistent body of literature on CCD governance at local levels is lacking, it is not possible to compare findings from this research with similar case studies.

The concepts of internal and external policy coherence supported the analysis of the alignment between adaptation and mitigation, and between climate and development objectives in local development planning. Evidence from this research suggests that climate change strategies are not integrated in formal development planning within Muheza District. Integrated approaches to development policy and planning are a cornerstone of $C C D$, as they can provide a long-term framework for the integration between development and climate change. Lebel et al. [41] observed that climate mainstreaming is a multi-level process, involving stakeholders from the national to local levels. Shemdoe et al. [9] (p. 23) suggests that the local levels in Tanzania, especially District Councils, represent a key entry point 'for mainstreaming climate change activities into the overall planning and budgeting process at the national level', due to the bottom-up approach in national development planning. However, findings from this research suggest that, despite the presence of institutional arrangements for the integration of climate change and development strategies, the capacity to move towards CCD in development planning at sub-national levels is limited due to a number of barriers. The research also highlights that, to a certain extent, the integration of climate and development strategies is taking place through external projects and on the ground activities, outside the formal development planning process. Dyer et al. [26] already observed that single projects might support the transition towards CCD. However, Pervin et al. [20] pointed out that project-based approaches are usually based on short-term objectives. As such, it has been noted that the inclusion of climate change measures in development planning is necessary to achieve long-term integration [41].

The analysis of barriers to CCD, based on Moser and Ekstrom's [32] framework, suggests that the response capacity at local levels, defined as the ability to reduce greenhouse gases emissions and to manage climate change risks and impacts [33], is influenced from both local and national level processes. Whilst multiple barriers were identified, under-resourcing was the most reported. This largely aligns with the empirical assessment of barriers to CCD from Ellis et al. [31]. The role of values and beliefs in influencing the integration process is not clear. For instance, despite awareness and belief that climate change is widespread across levels, development objectives at different levels do not always align with climate objectives, as they relate to short-term needs (especially at the village level). Measham et al. [42] observed that competing priorities might reduce attention for climate issues. The lack of information on climate impacts is another relevant barrier to the integration of climate change and development across sub-national levels. This is a commonly reported to the integration of climate change in local development planning. It has been observed that local planners usually lack relevant climate information for the scale at which they operate [43]. This was prominent in Muheza District, where only regional climate and weather predictions are available to the District Council. Moreover, insufficient communication across levels (namely, villages and the District Council) affects the awareness of local communities' vulnerability to climate variability within the District Council. The institutional context in which local authorities operate, not included in the initial framework, appears as a constraint to the integration of climate change in local planning. For instance, the lack of climate change considerations in key national development policies might be a key factor determining the absence of mitigation and adaptation measures in local development plan. Although climate change is being addressed in a series of national policies in Tanzania (the National Adaptation Programme of Action and the National Climate Change Strategy), it is not integrated in the 2025 
Tanzania Development Vision (2025 TDV) [10]. This suggests that the 2025 TDV has a high resonance in local development planning, as the development priorities defined in the local 5YDP align with the 2025 TDV. Previous research shows that the lack of climate change consideration in national policies constitutes a barrier to climate action at local levels, which usually have to comply with priorities established at higher levels [42].

CPI and investigation of barriers provide some insight on the multi-level character of CCD. Findings from this research suggest that CCD at the local level cannot be considered in isolation from the national level. Previous research on planned adaptation suggests that national climate measures affect climate activities at sub-national levels [44]. In Muheza District, integration has advanced further in the agriculture sector where national sectoral policy provides guidelines for the integration of climate change measures in local development. Although at the national level the institutional mandate for climate change policy lies within the Division of Environment in the Vice President's Office under the National Environmental Management Act (NEMA), the environmental sections within each ministry have the mandate to integrate climate change considerations in sectoral development plans $[10,40]$. However, few ministries have instituted environmental units, such as the Ministry of Agriculture and Ministry of Minerals and Energy [5]. As such, the integration of climate change in national policies is uneven across sectors. It is important to observe that, in some cases, in the void of specific national guidelines for action, local levels, supported by political leadership, are able to undertake climate action resorting to 'internal or external resources and information' [44] (p. 1082). In Muheza District, the District Council and local communities are lacking both sufficient resources and adequate information to integrate climate change measures in local development plans. As such, this case study suggests that moving towards CCD at the sub-national level is likely to require both building local capacity and including mitigation and adaptation in national development policies. For instance, building capacity within LGAs might facilitate the integration of information on local weather variability in local planning or facilitate the implementation of integrated actions that are still at the planning stage, such as conservation agriculture or sustainable land use management. Similarly, building capacity at the village level might prompt the integration of climate change measures in community banking schemes, such as the Village Community Bank (VICOBA). At the same time, mainstreaming climate change in national community development funds TASAF (Tanzania Social Action Fund) or in key national development strategies, such as the 2025 TDV, might provide an effective entry point for climate integration, given their economic and political relevance for local communities' development. This is consistent with the previous conceptualisation of CCD as a multi-level process [5].

This study points to the pivotal role that external stakeholders can play in the integration between development and climate change at sub-national levels. Dyer et al. [26] pointed out that public-private partnership provide another important channel for CCD. This research suggests that, in Muheza District, NGOs and external development partners are prominent in the climatisation of development. Thus, when the state capacity to engage with climate change is limited, NGOs and external development partners can take the initiative to integrate climate and development planning, as is the case for Muheza District. As such, partnership between LGAs and NGOs might be crucial to overcome some of the barriers to CCD, such as the lack of information on policy options or awareness of climate risks among government authorities. According to Clarke and de Cruz [27], compared to government authorities, NGOs have more capacity to work close to communities and address their development priorities. However, as shown in the analysis, climate-development integration is mainly taking place through conservation activities or forest co-management, excluding relevant sectors for CCD and local development in Muheza District, such as energy, industry, and infrastructure. Thus, coordination between external stakeholders and local authorities seems essential in order to ensure consistency between external development and conservation projects, and local development priorities. Indeed, Leventon et al. [21] (p. 321) emphasised that CSR projects not engaging 'with exiting 
plans and programmes, and with government and community actors' risk to undermine the public development agenda.

The research suggests that the (limited) integration between climate change and development activities taking place in Muheza District is not following the CCD approach as conceptualised by Mitchell and Maxwell [2]: development activities are mostly integrating adaptation measures to cope with climate extremes, such as livelihood diversification. Despite the potential for triple-wins offered by forest conservation or agroforestry, mitigation objectives are not being pursued, and respondents put more emphasis on the benefits of adaptation measures for local development. As already observed by Suckall et al. [12], the operationalization of CCD can be complicated by development's practitioners lack of expertise on climate change issues. In the case of Muheza District, respondents at all levels were rarely familiar with the concept of mitigation. At the same time, the close link between development and adaptation might be explained by Muheza District's socio-economic context, with local communities heavily reliant on natural resources for their livelihoods. In this case, synergies between development and adaptation might be more relevant to meet short-term development priorities, such as food security. Mitigation options might be less significant in socio-economic contexts responsible for a minimal amount of emissions, as is the case for Muheza District (a rural district) [19]. This supports Tanner et al.'s [19] interpretation of CCD as a dynamic process, where the degree of integration between the three CCD components changes over time and space, according to political priorities.

Several opportunities for advancing CCD emerge from the analysis, in line with the previous literature on CCD. Activities already implemented at the village level, such as agroforestry and forest conservation, or still at the planning stage, such as conservation agriculture, might provide an entry point for CCD. For instance, a Climate Smart Agriculture (CSA) approach might be adopted in the implementation of conservation agriculture and agroforestry activities. CSA, which encompasses both conservation agriculture and agroforestry, has been conceptualised as a group of agriculture strategies to increase soil quality and food production, remove greenhouse gases, and increase resilience [45]. Similarly, the extent to which forest conservation activities and forest co-management can contribute to mitigation, adaptation, and development aims in Muheza District could be assessed, since previous literature suggests that they can contribute to CCD $[12,46]$. However, the potential of both CSA and forest conservation to deliver triple-wins in Muheza District should be empirically assessed, as their effectiveness is sometimes questioned in the literature and it is strictly dependent on contextual factors, such as the degree of policy support $[45,46]$. However, more empirical research is needed to identify and assess options delivering triple-wins in a broader range of sectors, such as energy, infrastructure, and industry, which are likely to be prominent for local development priorities [12]. Finally, harnessing CCD opportunities would likely require raising awareness of climate change as a development issue among local stakeholders. Findings suggest that, in Muheza District, local stakeholders mainly conceive climate change as an environmental issue, linked to local environmental degradation and affecting rainfall patterns, and local ecosystems. However, it is widely acknowledged that the magnitude of climate change and its impacts are rooted in and affect socio-economic development pathways [47]. Raising awareness of climate change as a development issue might facilitate the inclusion of adaptation and mitigation measures in local development planning.

\section{Conclusions}

Climate change is already affecting human development and its impacts on socio-ecological systems are projected to increase in the future [39]. Since the factors determining climate change are deeply linked to the 'traditional' fossil-fuel-based development pathways, it has been argued that new approaches to development are needed [14]. The concept of CCD has been proposed as a policy framework to enhance human development, while at the same time reducing the risks posed by climate change. The aim of this research was to provide an initial assessment of LGAs' capacity to deliver CCD through local development planning. The concept of CPI was central to the scope of this 
study, as it allowed for the analysis of both formal development planning and governance processes at the local level.

Results from this study have implications for CCD theory and practice. The integration of adaptation, mitigation, and development strategies, central to the concept of $\mathrm{CCD}$, would require the coordination across a wide range of actors operating at different levels and sectors. Moving towards $\mathrm{CCD}$ at local levels would require both enhancing local actors capacity and building institutional arrangements conducive for integrated approaches to climate change and development, starting from the national level. Moreover, in contexts where LGAs have limited response capacity and formal institutional arrangements are ineffective in integrating climate and development objectives, external stakeholders might be taking the initiative to address climate change issues. In these cases, multi-stakeholder coordination might be crucial to ensure consistency between development and climate change objectives, as different actors might prioritise different objectives. This research also suggests that more effort is needed to include climate change considerations in formal development planning, in order to support a long-term engagement in CCD activities. If CCD is to become a new development landscape, the integration process should move beyond natural resources sectors, involving all sectors relevant to both development and climate change objectives.

Finally, this research suggests that moving towards CCD might require a flexible approach to the integration of adaptation, mitigation, and development. Though mitigation, adaptation, and development are equally considered in CCD original conceptualisation, stakeholders might put more or less emphasis on each component. Thus, the original representation of CCD as the outcome of a balanced progress in climate change and development objectives seems too rigid. In particular, the type and the degree of integration between adaptation, mitigation, and development might depend on 'political, social, cultural, economic and environmental context' [13] (p. 242). For instance, in developing rural contexts, co-benefits between adaptation and development, rather than triple-wins, can be more relevant to meet short-term development priorities. Thus, the implementation of CCD might require a context-based approach.

This study represents a first step in the analysis of CCD processes at sub-national levels. Since it is based on a single case study, the generalisability of its results might be questionable. However, it can be argued that the analytical approach applied in this research might be expanded to more case studies: the CPI framework developed by Di Gregorio et al. [23] can provide a useful starting point for a comparative analysis of policy and governance aspects of CCD. For instance, expanding the framework for analysis used in this study to other districts in Tanzania could clarify the extent to which the same multi-level institutional context, compared to other barriers, affects the integration of climate change in local development planning. A similar study could also be conducted in developed contexts. Indeed, it has been observed that there is limited evidence of measures to cope with climate change in developed countries, despite their higher response capacity [48]. However, as shown in this study, the CPI framework might not be enough to provide a comprehensive analysis of CCD processes, since opportunities for CCD might exist beyond formal planning or institutional arrangements. Moreover, this analysis has mainly focused on the planning stage of the climate change and development integration process, due to the limitations of this particular case study. Further research could investigate other stages of the process, in particular those relating to the implementation and the monitoring of CCD options. The framework could also be expanded to include the social and institutional learning processes, not included in this study.

Acknowledgments: This research was conducted under the COSTECH research permit number: 2016-366-NA-2016-101. Data collection was funded by the Economic and Social Research Council (UK) through the ESRC Centre for Climate Change Economics and Policy, with travel and subsistence support provided through the European Commission funded GCCA+ Tanzania project entitled 'Integrated Approaches for Climate Change Adaptation in the East Usambara Mountains'. For more Information about the project: https:/ / muhezaclimatechange.wordpress.com. This research formed part of the baseline research activities led by Susannah Sallu in December 2016. Giovanni Pilato supported this research whilst studying for his MSc. Climate Change and Environmental Policy at the University of Leeds. A copy of the full research report is available from Susannah Sallu, email: s.sallu@leeds.ac.uk. 
Author Contributions: Giovanni Pilato conducted two interviews, analysed the full data set, and drafted the paper. Susannah Sallu designed and led the field research, supervised the analysis of data, and supported the writing and submission of the paper. Marta Gaworek-Michalczenia supported research design and data collection and supervision of the MSc research and provided useful editorial suggestions during the writing of the paper.

Conflicts of Interest: The authors declare no conflict of interest.

\section{Appendix A}

Interview guide for interviews with village leaders:

1. Can you please explain your role(s) in the village?

2. How long have you been in this role?

3. When was the village established? What are the sub-villages?

4. Are there any particular challenges/difficulties the village faces?

5. Can you tell us about the weather/climate in your village?

6. Is your village affected by the weather and climatic issues? Explain.

7. Is any sub-village more or less affected?

8. Are the villagers coping and adapting to these weather and climatic issues. Explain.

9. Does the village/villagers receive any support (within or external) in relation to this? Explain. What? From whom?

10. Are people working together to overcome challenging times? Explain.

11. Does the village get information about the weather and climate? Explain. Who? What?

12. Are people in the village interested to learn (more)? Is the village active in this regard? Explain. Is anything limiting them being active/from learning?

13. What development ambitions does the village have? What are in your plans and do all villagers agree?

14. Can you explain how the village presents its ideas for development to the ward and district?

15. Are your ideas taken forward? Explain achievements/outcomes and/or challenges and anything limiting your ideas being taken forwards.

16. Do you have anything further you would like to discuss or any questions for us?

Interview guide for interviews with ward leaders and Councilors:

1. Can you please explain your role(s) in the ward?

2. How long have you been in this role?

3. How did you come to be in this role-what is your education?

4. Are there any particular challenges/difficulties the ward faces?

5. Can you tell us about the weather/climate in your ward?

6. Is your ward affected by the weather and climatic issues? Explain.

7. Is any village or sub-village in your ward more or less affected?

8. Are the villages in your ward coping and adapting to these weather and climatic issues. Explain.

9. Does the ward receive any support (within or external) in relation to this? Explain. What? From whom?

10. Are people working together in your ward to overcome challenging times? Explain.

11. Do you or the villages get information about the weather and climate? Explain. Who? What?

12. Are people in your ward interested to learn (more)? Are villagers in your ward active in this regard? Explain. Is anything limiting them being active/from learning?

13. What development ambitions does the ward (and the villages in it) have? What are your plans?

14. Can you explain how ideas for development are shared between village, ward and district?

15. How do you feel the GCCA/TFCG/ONGAWA project is going? Explain.

16. Do you have anything further you would like to discuss or any questions for us? 
Interview guide for interviews with district staff:

The following questions were used as a guide and adapted to each respondent. Not all questions were asked of all respondents.

\section{RESPONDENT DETAILS}
$1.1 \quad$ Name:
1.2 Role:
1.3 How long have you been in this role?
1.4 (If only recently in role/position)? Who was in this role before you?
1.5 What are your key responsibilities?
1.6 Which other roles have you been in previously?
1.7 Can you tell me about your educational background?
1.8 (if necessary) Can you briefly explain the role of your department.

2. AWARENESS AND KNOWLEDGE ABOUT WEATHER, CLIMATE IMPACTS, AND RESPONSES:

2.1 How is your district affected by the weather?

2.2 Does the weather vary across the district? Yes/No If yes, please explain.

2.3 How does the weather vary during the year? Please explain.

2.4 Does the weather vary from year to year? Yes/No If yes, please explain.

2.5 Has the district experienced any extreme or unexpected weather events? Examples:

2.6 How did these events affect people in the district?

2.7 Do you think the weather has changed at all? Yes / No Please explain your answer.

2.8 What do you understand by the concept of 'climate change'?

2.9 What are your thoughts on the causes of climate change?

2.10 What has informed your thinking? If experience, what? If taught, who? If information/evidence, what and how/where was it accessed?

2.11 Do you think climate change is affecting the district? Yes/No Please explain.

2.12 Do you think climate change will affect the district in the future? Yes/No Please explain.

2.13 What is most impacted by climate change (or extreme/unexpected event mentioned earlier) in the district? Why? What? (livelihoods, sectors, lands, regions, infrastructure, services, etc.) Why?

2.14 Who is most impacted by climate change in the district? Why? (wards, women, children, elders, particular livelihood groups, etc.) Why?

2.15 Are there any particular parts of the district that are more impacted than others? Where? Why?

2.16 (If focus on urban/rural impacts only, or rural/urban not mentioned expand the question to cover the other not previously mentioned) What impacts of climate change are, or do you envisage, the rural/urban population experiencing? Rural: Urban:

2.17 (If not mentioned) Are there any particular sectors that are, or you envisage being, most affected by climate change? Please explain.

2.18 (If focus on negative or positive impacts only, expand the question to cover the other possibility) Are there positive as well as negative impacts of climate change/events? OR Are there negative as well as positive impacts? Please explain.

\section{CLIMATE CHANGE STRATEGY, POLICY, and PLANNING-DEPARTMENT}

3.1 Is climate change being considered within planning in your department? Explain.

3.2 Are there any other specific initiatives (policies or strategies) (not previously mentioned) that are in progress or under development in your department? Explain. 
3.3 Has there been any specific actions (programmes or projects) directly taken to deal with climate change in your department? Explain. (IF NO PROCEED TO 3.4). For both 3.2 and 3.3 answers:

- What is their focus (Adaptation, Mitigation, Development, or an integration thereof)?

- Who is involved?

- Is it funded/is there a budget (who, how much, where from); do you get the money when you need it?

- Do implementation plans exist? E.g., Are there targets/actions?

- What is the timeline?

- What are the achievements so far? OR What opportunities do you envisage?

- What challenges have been faced?/What challenges do you envisage facing?

- Are there any gaps in knowledge or capacity among any of the actors/ institutions involved?

- What are the strengths and weaknesses of actors/institutions involved?

Look out for activities/initiatives that:

a) Support people to spontaneously cope with and adapt to change (assist people to adapt in practice) (supporting adaptive capacity) (A)?

b) Support people to prevent negative impacts that could happen in future (supporting adaptive capacity) (A)?

c) Support people to cope with impacts and adapt after events have been experienced (A, D)? (supporting recovery)

d) Stop climate change, slow climate change down, or stop it from creating future negative impacts (reduce emissions) $(\mathrm{M})$ ?

e) Harness opportunities associated with climate change (A, D)?

3.4 Are there any higher-level initiatives (national/ministerial/sectoral/district level policies, strategies, or programmes) currently in place that exist to support and guide departmental climate change initiatives? Explain (see prompts above).

3.5 Do you have any obligation to report about actions related to climate change? If yes, to whom, how often?

3.6 Which actors and institutions do you think should be involved and leading on planning, strategy, and implementation of climate change initiatives in your department? Who and why? Any support needed? Are there any gaps in knowledge or capacity among any of the actors/institutions involved?

3.7 Does your department have access to information about weather conditions such as weather forecasts, weather warnings, or similar? Yes/No If yes, what? Who has access to information, why?

And for each: Who provides the information? Is it used? If yes, by whom and how? Is it useful? Yes/No Explain answer.

3.8 Do you have any (other) ideas what your department should or could do in relation to climate change? Yes/No

If yes, explain. How? Budget? What is the timeline for action? Who? Why? Is support, or would support be, needed (e.g., finance, knowledge, training, and capacity development) to implement/achieve this? If yes, what? 
3.9 If no to 3.1-3.4, what is limiting action in your department on Climate change?

3.10 If no to 3.1-3.4, what would be the best way to incorporate climate change into your department's working? Is support, or would support be, needed (e.g., finance, knowledge, training, and capacity development) to implement/achieve this? If yes, what?

3.11 Is there potential or interest in integrating adaptation AND mitigation with development in planning? Why? Who is interested? How will this be achieved? What opportunities and challenges do you envisage in doing so? Is support, or would support be, needed (e.g., finance, knowledge, training, and capacity)

Interview guide for interviews with NGOs staff:

1. What is your position and role within your organisation? What are you responsibilities? How long have you been in your position?

2. Can you tell me about your personal experience in Muheza District?

3. What do you think the development priorities are in Muheza District?

4. Do you think there is a relation between climate change and development in Muheza District? What kind of relationship?

5. Were/Are you involved in projects concerning climate change mainstreaming in local development? Can you tell me about these projects?

6. Who was involved in the project? Why?

7. What do you think the challenges are in integrating climate change measures in development activities in Muheza District?

8. What do you think the opportunities are in integrating climate change measures in development activities in Muheza District?

9. What are the future projects of your organisation in Muheza District?

\section{References}

1. Downing, T.E.; Munasinghe, M.; Depledge, J. Special Supplement on Climate Change and Sustainable Development. Clim. Policy 2003, 3SI, S3-S8. [CrossRef]

2. Mitchell, T.; Maxwell, S. Defining Climate Compatible Development, CDKN ODI Policy Brief; Climate and Development Knowledge Network: London, UK, 2010.

3. Ficklin, L.; Stringer, L.C.; Dougill, A.J.; Sallu, S.M. Climate compatible development reconsidered: Calling for a critical perspective. Clim. Dev. 2017, 1-4. [CrossRef]

4. Tompkins, E.L.; Mensah, A.; King, L.; Long, K.; Lawson, E.T.; Hutton, C.; Anh, V.; Gordon, C.; Fish, M.; Dyer, J.; et al. An Investigation of the Evidence of Benefits from Climate Compatible Development; Sustainability Research Institute (SRI): Leeds, UK, 2013; pp. 1-31.

5. Stringer, L.C.; Sallu, S.M.; Dougill, A.J.; Wood, B.T.; Ficklin, L. Reconsidering climate compatible development as a new development landscape in Southern Africa. In Making Climate Compatible Development Happen; Nunan, F., Ed.; Routledge: Oxon, UK, 2017; pp. 22-43.

6. Suckall, N.; Tompkins, E.; Stringer, L. Identifying trade-offs between adaptation, mitigation and development in community responses to climate and socio-economic stresses: Evidence from Zanzibar, Tanzania. Appl. Geogr. 2014, 46, 111-121. [CrossRef]

7. Jack, C. Climate Projections for United Republic of Tanzania. 2011. Available online: http:/ / www.tzdpg.or.tz/ fileadmin/_migrated/content_uploads/Climate_projections_CCE_report_01.pdf (accessed on 9 January 2018).

8. Niang, I.; Ruppel, O.C.; Abdrabo, M.A.; Essel, A.; Lennard, C.; Padgham, J.; Urquhart, P. Africa. In Climate Change 2014: Impacts, Adaptation, and Vulnerability. Part A: Global and Sectoral Aspects. Contribution of Working Group II to the Fifth Assessment Report of the Intergovernmental Panel on Climate Change; Barros, V.R., Dokken, M.D., Mastrandrea, K.J., Mach, T.E., Bilir, M., Chatterjee, K.L., Ebi, Y.O., Estrada, R.C., Genova, B.G., Kissel, E.S., et al., Eds.; Cambridge University Press: Cambridge, UK; New York, NY, USA, 2014; pp. 1199-1265. 
9. Shemdoe, R. Climate Governance and Development: Case Study Tanzania. 2013. Available online: https: / / za.boell.org/sites/default/ files/downloads/Tanzania_long_doc_low_res.pdf (accessed on 9 January 2018).

10. Daly, M.E.; Yanda, P.Z.; West, J.J. Climate Change Policy Inventory and Analysis for Tanzania. 2015. Available online: https: / /www.cicero.uio.no/en/publications/internal/2825 (accessed on 9 January 2018).

11. Nindi, S.J. Final Report on Institutional Capacity Needs and Entry Points for Mainstreaming Climate Change Adaptation into Development Planning in Tanzania. 2012. Available online: https: //www.unpei.org/sites/default/files/e_library_documents/Institutional_Capacity_Needs_and_Entry_ Points_for_Mainstreaming_Climate_Change_Adaptation_into_Development_Planning_in_Tanzania.pdf (accessed on 9 January 2018).

12. Suckall, N.; Stringer, L.C.; Tompkins, E.L. Presenting Triple-Wins? Assessing Projects that Deliver Adaptation, Mitigation and Development Co-benefits in Rural Sub-Saharan Africa. aMbio 2015, 44, 34-41. [CrossRef] [PubMed]

13. Nunan, F. Prospects and challgenges for climate compatible development. In Making Climate Compatible Development Happen; Nunan, F., Ed.; Routledge: Oxon, UK, 2017; pp. 242-254.

14. Nunan, F. Conceptualising Climate Compatible Development. In Making Climate Compatible Development Happen; Nunan, F., Ed.; Routledge: Oxon, UK, 2017; pp. 1-21.

15. Fisher, S. Low-Carbon Resilient Development in the Least Developed Countries; IIED: London, UK, 2013.

16. Klein, R.J.T.; Schipper, E.L.F.; Dessai, S. Integrating mitigation and adaptation into climate and development policy: Three research questions. Environ. Sci. Policy 2005, 8, 579-588. [CrossRef]

17. Stringer, L.C.; Dougill, A.J.; Dyer, J.C.; Vincent, K.; Fritzsche, F.; Leventon, J.; Falcão, M.P.; Manyakaidze, P.; Syampungani, S.; Powell, P.; et al. Advancing climate compatible development: Lessons from southern Africa. Reg. Environ. Chang. 2014, 14, 713-725. [CrossRef]

18. Wilbanks, T.J. Integrating climate change and sustainable development in a place-based context. Clim. Policy 2003, 3 (Suppl. S1), 147-154. [CrossRef]

19. Tanner, T.; Mensah, A.; Lawson, E.T.; Gordon, C.; Godfrey-Wood, R.; Cannon, T.A.; Lawson, E.T.; Gordon, C.; Godfrey-Wood, R.; Cannon, T. A Political Economy of Artisanal Fisheries and Climate Change in Ghana. In Making Climate Compatible Development Happen; Nunan, F., Ed.; Routledge: Oxon, UK, 2017; pp. $223-241$.

20. Pervin, M.; Sultana, S.; Phirum, A.; Camara, I.F.; Nzau, V.M.; Phonnasane, V.; Khounsy, P.; Kaur, N.; Anderson, S. A Framework for Mainstreaming Climate Resilience into Development Planning; International Institute for Environment and Development: London, UK, 2013.

21. Leventon, J.; Dyer, J.C.; Van Alstine, J.D. The private sector in climate governance: opportunities for climate compatible development through multilevel industry-government engagement. J. Clean. Prod. 2015, 102, 316-323. [CrossRef]

22. Harkes, I.H.T.; Drengstig, A.; Kumara, M.P.; Jayasinghe, J.M.P.K.; Huxham, M. Shrimp aquaculture as a vehicle for Climate Compatible Development in Sri Lanka. The case of Puttalam Lagoon. Mar. Policy 2015, 61, 273-283. [CrossRef]

23. Di Gregorio, M.; Nurrochmat, D.R.; Paavola, J.; Sari, I.M.; Fatorelli, L.; Pramova, E.; Locatelli, B.; Brockhaus, M.; Kusumadewi, S.D. Climate policy integration in the land use sector: Mitigation, adaptation and sustainable development linkages. Environ. Sci. Policy 2016, 67, 35-43. [CrossRef]

24. Swart, R.; Raes, F. Making integration of adaptation and mitigation work: mainstreaming into sustainable development policies? Clim. Policy 2007, 7, 288-303. [CrossRef]

25. Nalau, J.; Preston, B.L.; Maloney, M.C. Is adaptation a local responsibility? Environ. Sci. Policy 2015, 48, 89-98. [CrossRef]

26. Dyer, J.; Leventon, J.; Stringer, L.; Dougill, A.; Syampungani, S.; Nshimbi, M.; Chama, F.; Kafwifwi, A. Partnership Models for Climate Compatible Development: Experiences from Zambia. Resources 2013, 2, 1-25. [CrossRef]

27. Clarke, M.; de Cruz, I. A climate-compatible approach to development practice by international humanitarian NGOs. Disasters 2015, 39, s19-s34. [CrossRef] [PubMed]

28. Bizikova, L.; Robinson, J.; Cohen, S. Linking climate change and sustainable development at the local level. Clim. Policy 2007, 7, 271-277. [CrossRef]

29. Wilbanks, T.J. Scale and sustainability. Clim. Policy 2007, 7, 278-287. [CrossRef]

30. Thornton, P.K.; Jones, P.G.; Alagarswamy, G.; Andresen, J. Spatial variation of crop yield response to climate change in East Africa. Glob. Environ. Chang. 2009, 19, 54-65. [CrossRef] 
31. Ellis, K.; Cambray, A.; Lemma, A. Drivers and Challenges for Climate Compatible Development; Working Paper; Climate and Development Knowledge Network: London, UK, 2013.

32. Moser, S.C.; Ekstrom, J.A. A framework to diagnose barriers to climate change adaptation. Proc. Natl. Acad. Sci. USA 2010, 107, 22026-22031. [CrossRef] [PubMed]

33. Tompkins, E.L.; Adger, W.N. Defining response capacity to enhance climate change policy. Environ. Sci. Policy 2005, 8, 562-571. [CrossRef]

34. Sémhur. Locator Map of Tanga Region. 2009. Available online: https://commons.wikimedia.org/w/index. php?curid=6686979 (accessed on 12 January 2018).

35. United Republic of Tanzania (URT). Tanga Region Socio-Economic Profile; Joint publication by National Bureau of Statistics and Tanga Regional Commissioner's Office; United Republic of Tanzania: Dar es Salaam, Tanzania, 2008.

36. United Republic of Tanzania (URT). Muheza District Council Five Years Development Plan; Regional Administrative and Local Government: Muheza, Tanzania, September 2012.

37. Fereday, J.; Muir-Cochrane, E. Demonstrating rigor using thematic analysis: A hybrid approach of inductive and deductive coding and theme development. Int. J. Qual. Methods 2006, 5, 80-92. [CrossRef]

38. Hsieh, H.-F.; Shannon, S.E. Three approaches to qualitative content analysis. Qual. Health Res. 2005, 15, 1277-1288. [CrossRef] [PubMed]

39. Denton, F.; Wilbanks, T.J.; Abeysinghe, A.C.I.; Burton, I.; Gao, Q.; Lemos, M.C.T.; Masui, T.; O’Brien, K.L.; Warner, K. Climate-resilient pathways: Adaptation, mitigation, and sustainable development. In Climate Change 2014: Impacts, Adaptation, and Vulnerability. Part A: Global and Sectoral Aspects. Contribution of Working Group II to the Fifth Assessment Report of the Intergovernmental Panel on Climate Change; Field, C.B., Barros, V.R., Dokken, D.J., Mach, K.J., Mastrandrea, M.D., Bilir, T.E., Chatterjee, M., Ebi, K.L., Genova, R.C., Girma, B., et al., Eds.; Cambridge University Press: Cambridge, UK; New York, NY, USA, 2014; pp. 1101-1132.

40. Nunan, F.; Campbell, A.; Foster, E. Environmental mainstreaming: the organisational challenges of policy integration. Public Adm. Dev. 2012, 32, 262-277. [CrossRef]

41. Lebel, L.; Li, L.; Krittasudthacheewa, C.; Juntopas, M.; Vijitpan, T.; Uchiyama, T.; Krawanchid, D. Mainstreaming climate change adaptation into development planning. Bangkok Adapt. Knowl. Platf. Stock. Environ. Inst. 2012, 8, 1-24.

42. Measham, T.G.; Preston, B.L.; Smith, T.F.; Brooke, C.; Gorddard, R.; Withycombe, G.; Morrison, C. Adapting to climate change through local municipal planning: barriers and challenges. Mitig. Adapt. Strateg. Glob. Chang. 2011, 16, 889-909. [CrossRef]

43. Amundsen, H.; Berglund, F.; Westskogh, H. Overcoming barriers to climate change adaptation-a question of multilevel governance? Environ. Plan. C Gov. Policy 2010, 28, 276-289. [CrossRef]

44. Westerhoff, L.; Keskitalo, E.C.H.; Juhola, S. Capacities across scales: local to national adaptation policy in four European countries. Clim. Policy 2011, 11, 1071-1085. [CrossRef]

45. Arakelyan, I.; Moran, D.; Wreford, A. Climate smart agriculture: a critical review. In Making Climate Compatible Development Happen; Nunan, F., Ed.; Routledge: Oxon, UK, 2017.

46. Quan, J.; Naess, L.O.; Newsham, A.; Sitoe, A.; Corrál Fernandez, M. The Political Economy of REDD+ in Mozambique. Implications for Climate Compatible Development. In Making Climate Compatible Development Happen; Nunan, F., Ed.; Routledge: Oxon, UK, 2017; pp. 151-181.

47. Parry, M. Climate change is a development issue, and only sustainable development can confront the challenge. Clim. Dev. 2009, 1, 5-9. [CrossRef]

48. Ford, J.D.; Berrang-Ford, L.; Paterson, J. A systematic review of observed climate change adaptation in developed nations. Clim. Chang. 2011, 106, 327-336. [CrossRef]

(C) 2018 by the authors. Licensee MDPI, Basel, Switzerland. This article is an open access article distributed under the terms and conditions of the Creative Commons Attribution (CC BY) license (http:/ / creativecommons.org/licenses/by/4.0/). 